Journal of Fisheries International 4 (4): 83-90, 2009

ISSN: 1817-3381

(C) Medwell Journals, 2009

\title{
Preliminary Assessment of Major Tilapiine Fishes Exploited by Artisanal Gillnet Fishery in Lake Ayame I (Bia Basin, Cote d'Ivoire)
}

\author{
${ }^{1}$ L. Tah, ${ }^{2}$ K.S. Da Costa, ${ }^{3}$ V.N. Douba, ${ }^{3}$ J.N. Kouassi and ${ }^{4}$ J. Moreau \\ ${ }^{1}$ Centre de Recherches Oceanologiques (C.R.O.) B.P.V. 18, Abidjan, Cote d'Ivoire \\ ${ }^{2}$ Centre National de Recherche Agronomique (CNRA), \\ Programme Peche et Aquaculture Continentales (PPAC), 08 B.P. 33, Abidjan 08, Cote d'Ivoire \\ ${ }^{3}$ Laboratoire d'Hydrobiologie, Université de Cocody, UFR Biosciences, \\ 22 B.P. 582, Abidjan 22, Cote d' Ivoire \\ ${ }^{4}$ Department of Inland Fisheries INP/ENSAT, B.P. 107, F. Auzeville Tolosane, \\ 31326 Castanet Tolosan, France
}

\begin{abstract}
Artisanal gillnet fishery was investigated in Ayamé I reservoir during a survey of 12 months. Mean value of Catch Per Unit Effort (CPUE) was $9.23 \pm 5.18 \mathrm{~kg}$ of fish per trip. Both commercially important tilapiine species, Sarotherodon melanotheron and Oreochromis niloticus, constituted $>57 \%$ of gillnet catches. The von Bertanlanffy growth parameters $\left(\mathrm{L}_{\infty}\right.$ and $\mathrm{K}$ ) computed from length-frequency data through the FiSAT software were $\left(\mathrm{L}_{\infty}=35.3 \mathrm{~cm}\right.$ and $\mathrm{K}=0.4$ year $\left.^{-1}\right)$ for $O$. niloticus and $\left(\mathrm{L}_{\infty}=33 \mathrm{~cm}\right.$ and $\mathrm{K}=0.55$ year $\left.^{-1}\right)$ for $S$. melanotheron. Resources status analysis by comparison of fishing mortality rates $\mathrm{F}$ with the target $\left[\left(\mathrm{F}_{\text {opt }}\right)\right.$ and limit $\left.\left(\mathrm{F}_{\text {limit }}\right)\right]$ ones, biological reference points indicated that $S$. melanotheron is overfished whereas, $O$. niloticus is exploited close to the optimum level. These results allowed us to suggest some management strategies for sustainable exploitation of the studied tilapiine stocks in the reservoir.
\end{abstract}

Key words: Artisanal fishery, sarotherodon melanotheron, oreochromis niloticus, resource status, artificial reservoir, France

\section{INTRODUCTION}

Artificial reservoirs play a significant role in fish production in several west African countries (Dugan, 2003). Published annual harvest data show production ranging from 1500 tons in Lake Manantali (Mali) to 40, 000 tons in Lake Volta (Ghana) (Leveque, 1999). An important characteristic of the tropical freshwater small-scale fishery is their multispecific nature, originating from the coexistence of many fisheries in the same river basin (Penha and Mateus, 2007). Among these types of fisheries, gillnets play an important role due to the large volume of fish landed and number of fishermen involved (Santos et al., 1995). Gillnets are widely used in the coastal and inland fisheries of the world because of their versatility, low cost, ease operation and efficiency in catches scattered fish (Balik and Çubuk, 2001).

The three to five most commercially and thus, socioeconomically important fish taxa from inland fisheries in west Africa include, tilapiine fishes whose estimates in country productions can be averaged at $20 \%$ (Abban et al., 2004). Their diversity consists of 2 species of Oreochromis, 6 species of Sarotherodon and 14 species of Tilapia (Leveque et al., 1992). In Cote d'Ivoire, the total annual yield of inland fisheries estimated at 18,000 tons are essentially dominated by Cichlidae, notably, Oreochromis niloticus which represents between $50-70 \%$ of the total catches (Gole-Bi et al., 2005). In Lake Ayame I, the fish population comprises actually seven tilapiines species (Gourene et al., 1999) including O. niloticus and Sarotherodon melanotheron.

Although, the tilapiine fishes contribute greatly in the economy of inland fisheries in Cote d'Ivoire, very limited studies concerning their dynamic and management are available. The present study is an attempt for the management of fish stocks in Lake Ayame I. It provides a preliminary assessment of Nile tilapia (O. niloticus) and Black-chinned tilapia (S. melanotheron) from artisanal gillnets catches based on length frequency distributions analysis.

\section{MATERIALS AND METHODS}

Study area: Lake Ayame I, the oldest hydroelectric dam of Cote d'Ivoire being commissioned for hydroelectric generation in 1959 (Reizer, 1967) has an average surface of

Corresponding Author: L. Tah, Centre de Recherches Oceanologiques (C.R.O.) B.P.V. 18 Abidjan, Cote d'Ivoire 


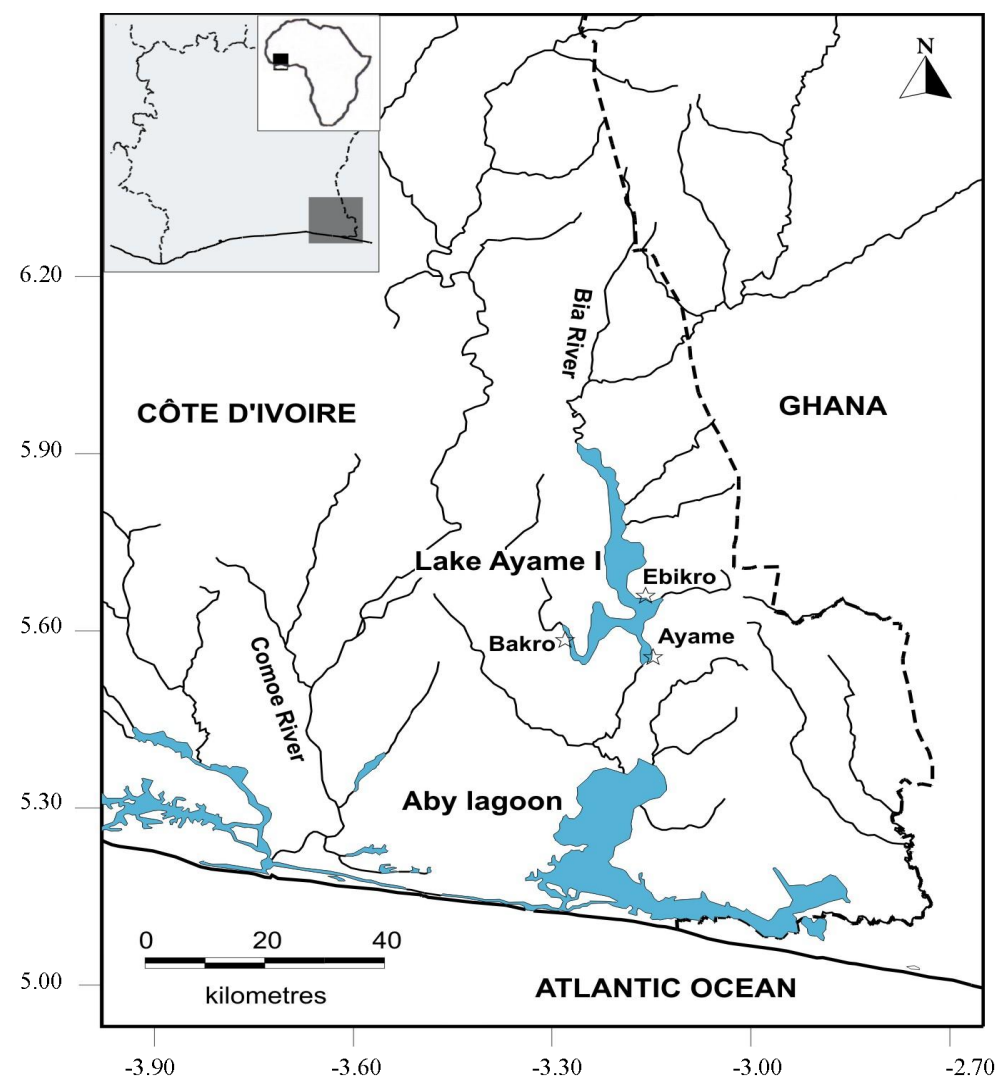

Fig. 1: Geographical location of lake Ayame I (Cote d'Ivoire) and sampling sites ( $\zeta$ ) (Tah et al., 2009)

$90 \mathrm{~km}^{2}$ and its maximum depth is $20 \mathrm{~m}$ (Gourene et al., 1999). The reservoir is situated at $3^{\circ}-3^{\circ} 5^{\prime} \mathrm{W}, 5^{\circ} 30^{\prime}-6^{\circ} \mathrm{N}$ in the Southeast of Cote d'Ivoire and the mean annual surface water temperature recorded is $28^{\circ} \mathrm{C}$ (Ouattara et al., 2007). During nearly four decades after its impoundment, the lake has been submitted to a continuous exploitation by traditional Bozo fishermen coming from a neighbouring country (Mali).

Recently, after a conflict between this fisher's community and autochthonous populations, nonindigenous fishermen were not permitted to fish in the lake (Tah et al., 2009). The fishery in lake Ayame I is purely artisanal and several fishing gears are used notably, gillnets, long lines, beach seines, cast nets and various kind of traps. However, fish production is mainly based on gillnets, beach seines and bamboo traps catches.

For this study, three stations (Ayame, Bakro and Ebikro) were chosen. They constitute the main fish landing sectors on the lake (Fig. 1). Furthermore, these three stations are useful for comparative purposes with previous studies (Gourene et al., 1999; Ouattara et al., 2006).
Data collection: Fish landings were sampled at the described three main landing sites every month, during 3-4 days per site, between August 2004 and July 2005. Total gillnet catches were weighed as the boats arrived. Then specific composition per catch was also determined. Besides, fishermen were chosen at random and all fishes in their catches were measured if the catch assemblage was about $5 \mathrm{~kg}$. Sampled specimens are measured individually to the $\mathrm{mm}$ (Total Length) and weighed to the nearest gram. Captured fishes were identified according to Leveque et al. (1992). Independently, gillnets characteristics (length, mesh-size, depth, number of gillnet per fisherman) were collected at every sampling site.

Data analysis:The unity of analysis was the fishing trip which corresponds to the activity of each fisherman in one day (fisherman go fishing only once each day). Only fishing trips from gillnets' fishermen were considered in this study. The fishing effort was considered as the daily fishing trip and Catches Per Unit Effort (CPUE) was defined as the quantity of fish caught $(\mathrm{kg})$ per fishing trip. The CPUE were estimated every month per landing site. The means CPUE were compared among sampling sites 
through one-way ANOVA, considering each fishing trip per day as a sample unit. The researchers also grouped the distinct in gillnet mesh sizes (mm, knot to knot), used by fishermen the following categories: small mesh sizes (10-25 mm), medium mesh sizes $(30-45 \mathrm{~mm})$ and large mesh sizes $(50-70 \mathrm{~mm})$.

In the present research, only two economically important tilapiine species, $O$. niloticus and $S$. melanotheron from gillnet catches were considered for length frequency analysis. Fish specimens of these populations from the three localities were respectively grouped in length class at $1 \mathrm{~cm}$ intervals. Lengthfrequency distributions were analyzed using the FiSAT (FAO-ICLARM Stock Assessment Tools) software (Gayanilo et al., 2002).

ELEFAN I program in FiSAT II was applied to estimate the growth parameters $\left(\mathrm{L}_{\infty}\right)$ and $(\mathrm{K})$ as assuming that the body growth follows the von Bertalanffy growth equation (Gayanilo et al., 2002) as following:

Where:

$$
\mathrm{L}(\mathrm{t})=\mathrm{L}_{\infty}\left(1-\exp \left(-\mathrm{K}\left(\mathrm{t}-\mathrm{t}_{0}\right)\right)\right)
$$

$\mathrm{L}(\mathrm{t})=$ The length at age

$\mathrm{t}, \mathrm{L}_{\infty}=$ The asymptotic length

$\mathrm{K}=\mathrm{A}$ growth coefficient

$\mathrm{t}_{0}=$ Correspond to the theoretical age at which the length is zero

ELEFAN I method fits the growth curve which passes throughout a maximum number of peaks in the length frequency distribution (Pauly, 1984). An index of goodness of fit, called (Rn) was determined by automatic computer generation (Gayanilo et al., 2002).

Once the growth parameters of von Bertalanffy growth function $\left(\mathrm{L}_{\infty}\right.$ and $\mathrm{K}$ ) were obtained, total mortality $Z$ was estimated by the length converted catch curve method as implemented in ELEFAN II. The linearized length-converted catch curve (Pauly, 1984) was constructed using the following equation:

Where:

$$
\operatorname{Ln}\left(\mathrm{N}_{\mathrm{i}} / \Delta \mathrm{t}_{\mathrm{i}}\right)=\mathrm{a}+\mathrm{bt}_{\mathrm{i}}
$$

$\mathrm{N}=$ The number of individuals in length class $\mathrm{i}$

$\Delta \mathrm{t}=$ The time needed for the fish to grow through length class $\mathrm{i}$

$\mathrm{t}=$ The relative age (computed with $\mathrm{t}_{0}=0$ ) corresponding to the mid-length of class I

The slope (b) of the curve with its sign changed gives $Z$. The regression lines were extrapolated to approximate the probability of capture given natural mortality (M). FiSAT II provides option to estimate this value using the empirical equation of Pauly (1980) as following:

$$
\begin{aligned}
& \log _{10}(\mathrm{M})=-0.0066-0.279 \log _{10}\left(\mathrm{~L}_{\infty}\right)+ \\
& 0.6543 \log _{10}(\mathrm{~K})+0.463 \log _{10}(\mathrm{~T})
\end{aligned}
$$

Where $\mathrm{T}$ is the annual mean of habitat temperature $\left({ }^{\circ} \mathrm{C}\right)$. The indicated value is equal here to $28^{\circ} \mathrm{C}$ (Ouattara et al., 2007). Fishing mortality F was obtained by subtracting $M$ from $Z$ and exploitation rate $E$ was obtained from $\mathrm{F} / \mathrm{Z}[\mathrm{E}=\mathrm{F} / \mathrm{Z}=\mathrm{F} /(\mathrm{F}+\mathrm{M})]$ (Gulland, 1971).

The extrapolated points of the length-converted catch curve were used to approximate the probability of capture for each length group using the running average method to estimate the length-at-first capture ( $\mathrm{Lc}$ or $\mathrm{L}_{50}$ ) through linear interpolation. In this study, the resource status was evaluated by comparing estimates of the fishing mortality rate $(\mathrm{F})$ with the target $\mathrm{F}_{\text {opt }}$ and limit $\mathrm{F}_{\text {limit }}$ ones, Biological Reference Points (BRP) which were defined as: $F_{\text {opt }}=0.5 \times \mathrm{M}$ and $\mathrm{F}_{\text {limit }}=2 / 3 \times \mathrm{M}$ (Patterson, 1992). These two categories of index were established in stocks management based on methods of population dynamics: Target Reference Points (TRPs) that define conditions desirable of a stock and Limit Reference Points (LRPs) that determine the critical values whose overtaking is dangerous for exploitation (Kantoussan, 2007).

\section{RESULTS AND DISCUSSION}

Gillnets' characteristics and catch composition: A total of 538 gillnets belonging to 76 fishers have been counted in the three sampling sites. Gillnets are made with monofilament polyester twines. Each net measured of $50 \mathrm{~m}$ long and $1.5-5 \mathrm{~m}$ depth with a hanging ratio $\mathrm{E}=0.30$. The twine diameter of monofilament nets were $0.16 \mathrm{~mm}$ for small mesh sizes, $0.20 \mathrm{~mm}$ for medium mesh size and $0.23 \mathrm{~mm}$ for large mesh sizes.

The allocation of these fishing gears within the mesh-size class was $24.3 \%$ (131) for small mesh sizes, $71.7 \%$ (386) for medium mesh sizes and 3.9\% (21) for large mesh sizes. Every fisherman uses an average of 7 gillnets per fishing trip (Table 1).

A yield of 5.5 tons performed by 592 fishing trips were registered at the three sampling sites from gillnets catches. About 403 fishing trips, cumulating a weight of 3.4 tons were used to determine catch composition. Four taxa ( $S$. melanotheron, Brycinus sp., O. niloticus and Chrysichthys sp.) among the 38 ones identified in the catches, showed around $80 \%$ of the landed fish weight (Fig. 2). Furthermore, the two studied tilapiine species, $S$. melanotheron and $O$. niloticus, represented 44.3 and $13.3 \%$, respectively. 
Table 1: Mean Catch Per Unit Effort (CPUE) and related parameters (fishing trips: Nb. trips; total catch: catches (kg) and average number of nets per fisher: Gn fisher ${ }^{-1}$ ) registered during 2004-2005

\begin{tabular}{|c|c|c|c|c|c|c|c|}
\hline \multirow[b]{2}{*}{ Landing sectors } & \multicolumn{3}{|c|}{ Related parameters } & \multicolumn{4}{|c|}{ CPUE $\left(\mathrm{kg} \mathrm{trip}^{-1}\right)$} \\
\hline & Gn fisher $^{-1}$ & $\mathrm{Nb}$. trips & Catches (kg) & Min. & Max. & Mean & $\mathrm{SD}$ \\
\hline Ayamé & 8.7 & 197 & 2494.9 & 0.2 & 25.0 & 12.64 & 5.868 \\
\hline Bakro & 6.2 & 213 & 1506.4 & 0.2 & 22.0 & 7.07 & 5.000 \\
\hline Ebikro & 4.8 & 182 & 1501.5 & 0.6 & 23.3 & 8.25 & 4.686 \\
\hline Mean & 7.1 & - & - & - & - & 9.32 & 5.180 \\
\hline Total & - & 592 & 5502.8 & - & - & - & - \\
\hline
\end{tabular}

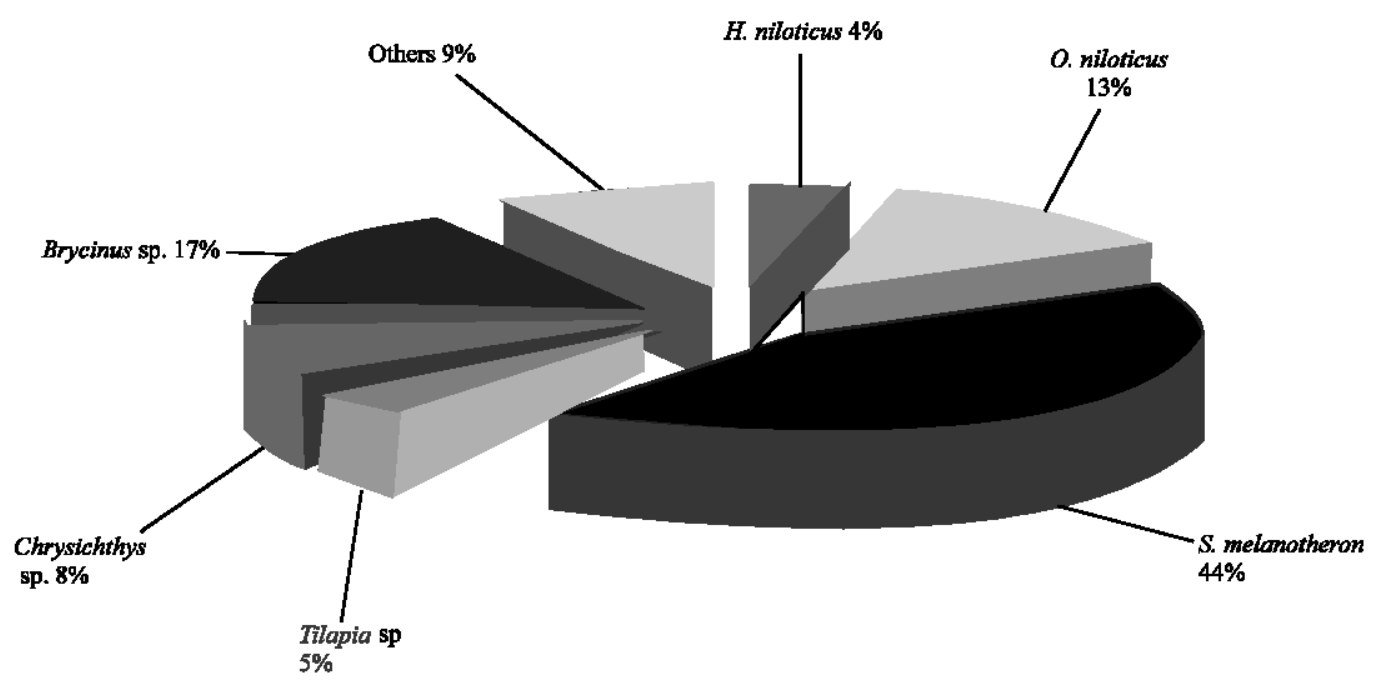

Fig. 2: Species composition by weight in gillnet catches from August 2004 to July 2005 (Tah et al., 2009)

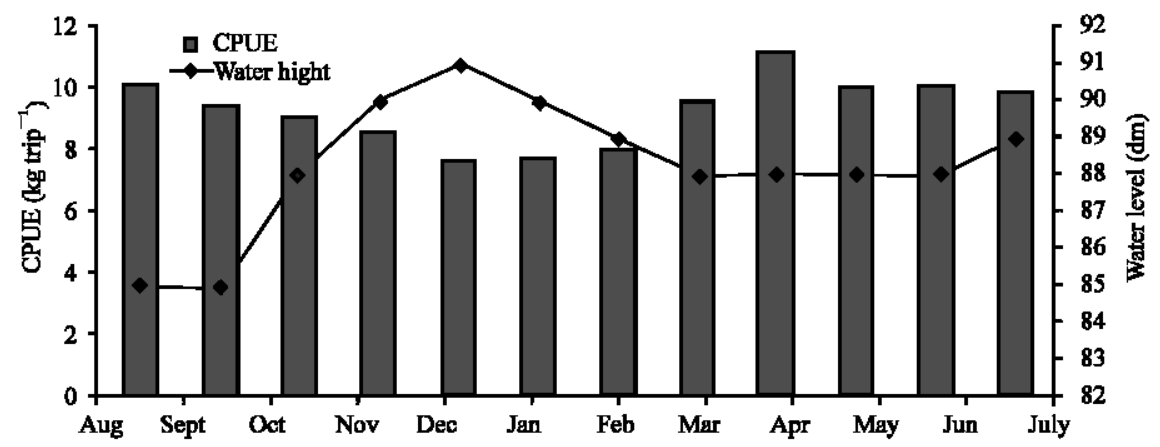

Fig. 3: Temporal variation of Catch Per Unit Effort (CPUE): $\mathrm{kg}$ trip $^{-1}$ ) and water level in lake Ayamé I from August 2004 to July 2005

Catches per fishing trip: The mean annual value of daily Catch Per Unit Effort (CPUE) varied from $7.07 \mathrm{~kg} \mathrm{trip}^{-1}$ at Bakro to $12.64 \mathrm{~kg} \mathrm{trip}^{-1}$ at Ayame. A comparison of the daily CPUE showed no significant difference among the two landing sites of Bakro and Ebikro.

However, a significant difference $(\mathrm{p}<0.050)$ appeared among Ayame sector $\left(12.64 \mathrm{~kg} \mathrm{trip}^{-1}\right)$ and two other sampling sites $\left(8.25\right.$ and $7.07 \mathrm{~kg} \mathrm{trip}^{-1}$ for Ebikro and Bakro). Besides, monthly changes of the mean CPUE and mean water level showed that the weakest values of CPUE are recorded in high waters while most elevated values of this index are observed in low waters (Fig. 3).

Growth parameters: A total of 842 and 1524 individuals of Nile tilapia (O. niloticus) and Black chin tilapia (S. melanotheron) were analyzed. Total length distributions were ranged from $11.5-33.5$ and $7.5-32.1 \mathrm{~cm}$ for $O$. niloticus and $S$. melanotheron, respectively. 
The asymptotic length $\mathrm{L}_{\infty}$ and growth coefficient $\mathrm{K}$ were estimated at $35.3 \mathrm{~cm}$ and 0.40 year $^{-1}$ for $O$. niloticus, $33 \mathrm{~cm}$ and 0.55 year $^{-1}$ for $S$. melanotheron (Table 2). For these estimates through ELEFAN I, Rn values was 0.210 for $O$. niloticus and 0.220 for $S$. melanotheron. The computed growth curves produced with these parameters have been shown over the original length distribution of individual species as shown in Fig. $4 a, b$. The value of $t_{0}$ was taken as 0 . Using the estimated value of the average growth coefficient $\mathrm{K}$, the longevity $\left(\mathrm{t}_{\max }=3 / \mathrm{K}\right)$ was to be 5 and 7 years for $S$. melanotheron and $O$. niloticus, respectively (Table 2 ).

Mortality rates and length at first capture $\left(L_{50}\right)$ : The annual rate of total mortality (Z) derived from length

Table 2: Estimated population parameters of two major tilapiine species caught in the artificial reservoir of Ayamé I from August 2004 to July 2005

\begin{tabular}{lcc}
\hline Parameters & O. niloticus & S. melanotheron \\
\hline $\mathrm{L}_{\mathrm{es}}(\mathrm{TL}, \mathrm{cm})$ & 35.30 & 33.00 \\
$\mathrm{~K}\left(\mathrm{year}^{-1}\right)$ & 0.40 & 0.55 \\
$\mathrm{Rn}$ & 0.21 & 0.22 \\
$\mathrm{Z}\left(\right.$ year $\left.^{-1}\right)$ & 1.42 & 2.87 \\
$\mathrm{M}\left(\mathrm{year}^{-1}\right)$ & 0.94 & 1.18 \\
$\mathrm{~F}\left(\mathrm{year}^{-1}\right)$ & 0.48 & 1.69 \\
$\mathrm{E}=\mathrm{F} / \mathrm{Z}$ & 0.34 & 0.59 \\
$\mathrm{M} / \mathrm{K}$ & 2.35 & 2.14 \\
$\mathrm{t}_{\text {max }}\left(\mathrm{Year}^{-1}\right)$ & 7.00 & 5.00 \\
$\mathrm{Lc}(\mathrm{TL}, \mathrm{cm})$ & 13.91 & 12.34 \\
$\mathrm{~F}_{\text {opt }}$ & 0.47 & 0.59 \\
$\mathrm{~F}_{\text {limit }}$ & 0.62 & 0.78 \\
\hline
\end{tabular}

frequency catch curves (Fig. 5a, b) was 1.42 year $^{-1}$ (between 2.74 and 7.44 years) for $O$. niloticus and 2.87 year $^{-1}$ for $S$. melanotheron (between 1.92 and 5.62 years). The natural mortality rate $\mathrm{M}$ derived from the Pauly's equation were estimated at 0.94 year $^{-1}$ for $O$. niloticus and 1.18 year $^{-1}$ for $S$. melanotheron. The values of $(\mathrm{M} / \mathrm{K})$ ratio were 2.35 and 2.14 for $O$. niloticus and $S$. melanotheron, respectively. The rates of fishing mortality $\mathrm{F}$ were 0.48 and 1.69 year $^{-1}$ for $O$. niloticus and S. melanotheron, respectively. The exploitation ratio $\mathrm{E}$ was 0.34 for $O$. niloticus and 0.59 for $S$. melanotheron (Table 2). The mean length at first capture $\left(\mathrm{L}_{50}\right)$ was estimated at $13.91 \mathrm{~cm}$ (TL) for $O$. niloticus and at $12.34 \mathrm{~cm}$ (TL) for $S$. melanotheron. The biological reference points calculated for $S$. melanotheron were $\mathrm{F}_{\text {opt }}=0.59$ and limit $\mathrm{F}_{\text {limit }}=0.78$. In the case of $O$. niloticus, these values were $\mathrm{F}_{\text {opt }}=0.47$ and $\mathrm{F}_{\text {limit }}=0.62$ (Table 2).

Like in most African fisheries, gillnets contribute widely at the capture of fish in the artificial reservoir of Ayamé I. The average CPUE in gillnets fishery was $9.3 \mathrm{~kg}$ per fishing trip per day. This value is relatively high in comparison with those reported in Ebrie Lagoon in Cote d'Ivoire (4.1 kg per trip) by Albaret and Lae (2003) and in Selengue Reservoir in Mali (3.42-8.19 $\mathrm{kg} \mathrm{trip}^{-1}$ ) by Lae et al. (2004). However, the result is lower than the CPUE recorded for Manantali Reservoir in Mali (8.81-13.56 $\mathrm{kg}_{\text {trip }^{-1}}$ ) by Lae et al. (2004). Highest mean CPUE (12.64
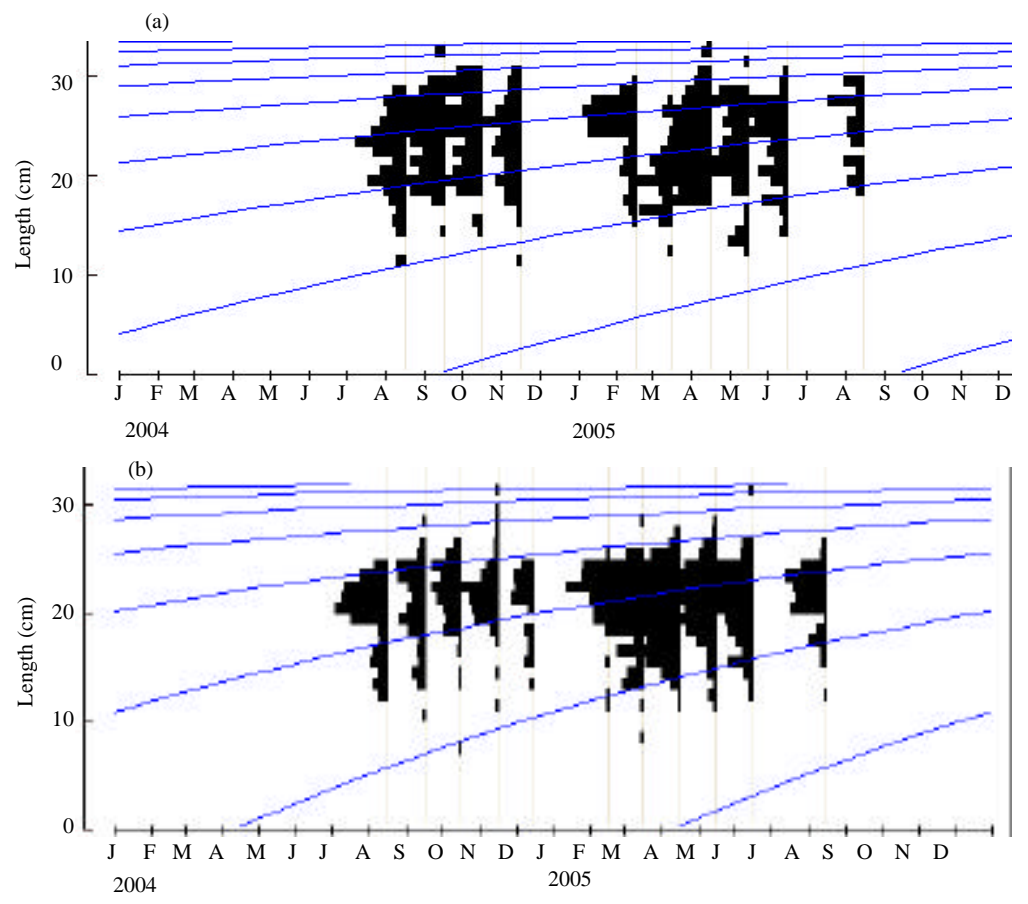

Fig. 4: Growth curves (continuous lines) of Oreochromis niloticus (a) and Sarotherodon melanohteron (b) cohorts from gillnets fishery in Lake Ayame 


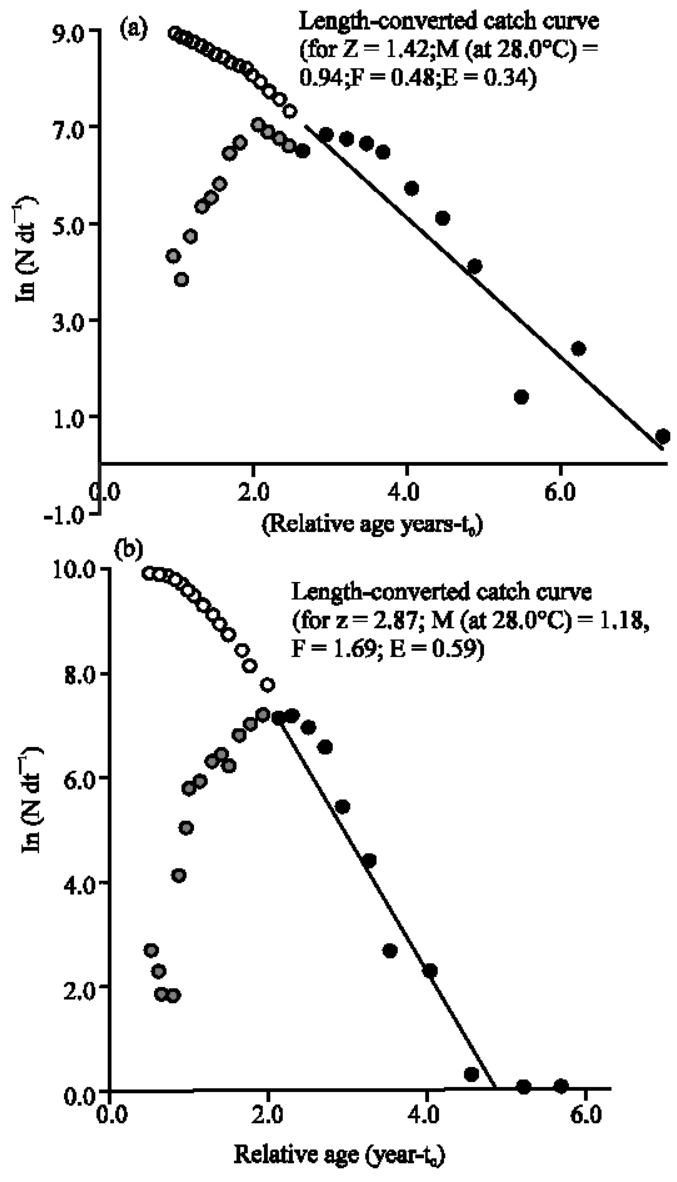

Fig. 5: Length-converted catch curves for estimating annual instantaneous total mortality $Z$ and natural mortality ( $\mathrm{M}$ at $28^{\circ} \mathrm{C}$ ) for (a) O. niloticus and (b) $S$. melanotheron from gillnets catches on Lake Ayame I. Black circles in the figure represent the points used in calculating $Z$ through least squares lines regression. The gray circles represent points either not fully recruited or nearing to $\mathrm{L}_{\infty}$ and hence, discarded from the calculation. The fishes that ought to have been caught (had not been due to the effect of incomplete selection/recruitment) are added white circles to the curve, with the ratio of expected numbers to those that were actually caught being used to estimate probabilities of capture

$\mathrm{kg}$ of fish trip ${ }^{-1}$ ) recorded at Ayame could be related to great fishing activities observed in this section. Indeed, this landing ground which represent the biggest landing site of the lake (Ouattara et al., 2006; Tah et al., 2009) is characterized by the high density of fishermen and by the great number of nets 8 used per fisherman per trip (Table 1).
Besides, changes in CPUE as a function of water level observed on the lake could be explained by fish behaviour in the lake as reported by Kantoussan (2007) in lakes Selingue and Manantali (Mali). According to this researcher, increasing of water level in the lake during the rainy seasons induct, fishes scattering in the water column for feeding or spawning. Thus, the dilution of fishes in the mass of water makes them less vulnerable to the fishing gears which induct a decline in CPUE during this period. With the decrease of the water level, individuals are concentrated in a weak volume of water. Fishes become, thus more accessible and more vulnerable to fishing gears.

Gillnet catches composition by weight recorded during the study was $S$. melanotheron (44\%), Brycinus sp. (17\%) O. niloticus (13\%), Chrysichthys sp. (8\%) and others (14\%) (Fig. 2). This composition is nearly identical to one of the total yield estimated by Tah et al. (2009) which was: S. melanotheron (57\%), Brycinus sp. (19\%), Chrysichthys sp. (10\%), O. niloticus (4\%) and others $(10 \%)$ during the same period. These results indicate the great contribution of the gillnet fishery in the landings on Lake Ayame I.

The values of $\mathrm{L}_{\infty}$ and $\mathrm{K}$ were calculated as $\left(\mathrm{L}_{\infty}=35.3\right.$ $\mathrm{cm} ; \mathrm{K}=0.4$ year $\left.^{-1}\right)$ and $\left(\mathrm{L}_{\infty}=33 \mathrm{~cm} ; \mathrm{K}=0.55\right.$ year $\left.^{-1}\right)$ for the Nile tilapia and the Black-chinned tilapia, respectively. The results also appeared to be of the right order in comparison with a range of published estimates of von Bertalanffy growth equation derived from length frequency (Table 2). In the present study, the estimates of the natural mortality rates $\left(\mathrm{M}=0.94\right.$ and $\left.1.18 \mathrm{year}^{-1}\right)$ for $O$. niloticus and $S$. melanotheron can be considered as reliable because of the $\mathrm{M} / \mathrm{K}$ ratio (2.31 and 2.14) are within the range of 1.12-2.50 (Table 3) calculated for most fish populations (Beverton and Holt, 1957). Besides, these results are close to those reported by previous study (Niyonkuru et al., 2003; Villanueva, 2004; Froese and Pauly, 2008; Moreau et al., 2008).

The specified precautionary target $\left(\mathrm{F}_{\text {opt }}=0.5 \times \mathrm{M}\right)$ and limit $\left(\mathrm{F}_{\text {limit }}=2 / 3 \times \mathrm{M}\right)$ values are considered to be appropriate biological reference points, in particular given current management objectives which are aimed at stock re-building and resource conservation ( Grandcourt et al., 2007).

In the study, the annual fishing mortality ( $\mathrm{F}=$ 1.69 year $^{-1}$ ) for $S$. melanotheron was considerably greater than the target $\left(\mathrm{F}_{\text {opt }}=0.59\right)$ and limit $\left(\mathrm{F}_{\text {limit }}=0.78\right)$ biological reference points suggesting that this stock was heavily exploited by gillnets fishery on the lake Ayamé I. Relating to $O$. niloticus, fishing mortality $(\mathrm{F}=0.48)$ was close to the target $\left(\mathrm{F}_{\mathrm{opt}}=0.47\right)$ and lower than $\left(\mathrm{F}_{\text {limit }}=0.62\right)$ indicating that this tilapiine stock was near the optimum exploitation level. 
Table 3: Von Bertanlanffy growth parameters and natural mortality rates of Sarotherodon melanotheron and Oreochromis niloticus from Lake Ayame I and

\begin{tabular}{|c|c|c|c|c|c|c|c|}
\hline Species & Area & Locality & Authors & Type of length & $\mathrm{L} 8(\mathrm{~cm})$ & $\mathrm{K}\left(\right.$ year $\left.^{-1}\right)$ & $\mathrm{M}\left(\mathrm{yr}^{-1}\right)$ \\
\hline \multirow{6}{*}{ O. niloticus } & Cote d'Ivoire & Lake Ayamé I & This study & $\mathrm{TL}$ & 35.3 & 0.400 & 0.940 \\
\hline & Kerya & Lake Victoria & FishBase 2008 & $\mathrm{TL}$ & 61.3 & 0.350 & - \\
\hline & Burkina Faso & Tanguiga Resevoir & FishBase 2008 & TL & 17.6 & 0.460 & - \\
\hline & Sri Lankan & Minneriya Reservoir & Moreau et al., 2008 & $\mathrm{TL}$ & 43.5 & 0.320 & 0.780 \\
\hline & Sri Lankan & Adawalawe Reservoir & Moreau et al., 2008 & $\mathrm{TL}$ & 44.0 & 0.490 & 1.010 \\
\hline & Sri Lankan & Victoria Reservoir & Moreau et al., 2008 & $\mathrm{TL}$ & 38.2 & 0.600 & 1.190 \\
\hline \multirow[t]{6}{*}{ S. melonotheron } & Cote d'Ivoire & Lake Ayamé & This study & $\mathrm{TL}$ & 33.0 & 0.550 & 1.180 \\
\hline & Benin & Lake Nokoué & Niyonkuru et al., 2003 & TL & 26.7 & 0.950 & 1.520 \\
\hline & Nigeria & Lagos Lagoon & FishBase, 2008 & TL & 31.1 & 0.159 & 1.900 \\
\hline & Senegal & Sine saloum & Villanueva, 2004 & FL & 22.0 & 0.600 & 1.081 \\
\hline & Gambia & Gambia Estuary & Villanueva, 2004 & FL & 37.0 & 0.390 & 0.893 \\
\hline & Cote d'Ivoire & Ebrié Lagoon & Villanueva, 2004 & FL & 34.0 & 0.420 & 0.976 \\
\hline
\end{tabular}

According to Penha and Mateus (2007), fishing target a broad range of lengths and ages but fishing recruitment may start only after the average size at the first maturation $\left(\mathrm{L}_{\mathrm{m}}\right)$ is reached. ndeed, this ensures that individuals are caught only after contributing to the maintenance of the stocks genetic diversity and minimizes the risks associated with the excessive concentration of the effort on larger sized groups which could remove individuals with the highest growth potential from the stock (Longhusrt, 2002). n the present study, estimated mean size at first capture for S. melanotheron $\left(\mathrm{L}_{\mathrm{c}}=12.34\right.$ $\mathrm{cm}$ TL) was smaller than the average size at first sexual maturity for females in Lake Ayame I $(\mathrm{Lm}=13.6 \mathrm{~cm} \mathrm{SL})$ as reported by Kone and Teugels (1999).

Concerning $O$. niloticus, the mean size at first capture $\left(\mathrm{L}_{\mathrm{c}}=13.91 \mathrm{~cm} \mathrm{TL}\right)$ is closed to the mean size at first sexual maturity for females ( $\mathrm{Lm}=13.5 \mathrm{~cm} \mathrm{SL}$ ) as calculated by Duponchelle and Legendre (2000). These observations corroborate the current high level of exploitation for the Black-chinned tilapia and the optimum level of exploitation for the Nile tilapia registered in gillnet fishery in the reservoir of Ayame I.

O. niloticus an introduced species (Moreau et al., 1988 ) and $S$. melanotheron a landlocked or introduced one (Gourène et al., 1999) are a highly commercial species in the lake Ayame I. Gourene et al. (1999) indicated a decline in the stock of $O$. niloticus and the reduction of the mean size at catch for $S$. melanotheron in this reservoir before the leaving of Bozo fishermen from the lake in 1998. About seven years after, this trend has been modified. Indeed, Tah et al. (2009) indicate the reappearance of $O$. niloticus and the presence of large sized specimens of $S$. melanotheron in the landings actually. These stocks seem to be reconstituting since the decrease of fishing pressure on the resources, after the departure of non-indigenes fishermen (Tah et al., 2009).

\section{CONCLUSION}

Thus, optimisation of fishing strategy should be considered by management authorities for the protection of these resources.
The gillnet fisheries management on Lake Ayame I could consists of the following actions increasing in mesh size regulation should be considered control of fishing efforts and fishing power through the establishment of fishing licence forbidden fishing during the reproductive period periodic prohibition from fishing of certain areas or creation of lake reserves. In other hand, there is urgent need to devolve fisheries management to the local level to compel fishers to take greater responsibility for the sustainability and conservation of the fisheries resources.

\section{ACKNOWLEDGEMENTS}

Researchers are grateful to the Ministry of Animal Resources and Fisheries Production of Cote d'Ivoire for financing this study.

\section{REFERENCES}

Abban, E.K., S. Agyakwa and T.M. Falk, 2004. Socioeconomic Importance of Tilapiine Fishes (Teleostei, Cichlidae). In: Biodiversity, Management and Utilisation of West African Fishes, Dugan, P. and T.M. Falk (Eds.). World Fish Center, Malaysia, pp: 63.

Albaret, J. and R. Lae, 2003. Impact of fishing on fish assemblages in tropical lagoons: The example of the Ebrie Lagoon, West Africa. Aquat. Living Resour., 16: 1-9.

Balik, L. and H. Çubuk, 2001. Effect of net colours on efficiency of monofilament gillnets for catching some fish species in lake beyksehir. Turk. J. Fish. Aquat. Sci., 1: 29-32.

Beverton, R.J.H. and S.J. Holt, 1957. On the dynamics of exploited fish populations. Fish. Invest. Ser. II, 19: 1-533.

Dugan, P., 2003. Investing in Africa: The world fish Center's African strategy in summary NAGA. NAGA, 26: 4-8.

Duponchelle, F. and M. Legendre, 2000. Oreochromis niloticus (Cichlidae) in lake ayame cote d'ivoire: Life history traits of a strongly diminished population. Cybium, 24: 161-172. 
Froese, R. and D. Pauly, 2008. Fishbase. World Wide Web Electronic Publication. http://www. fishbase.org/.

Gayanilo, F.C., P. Sparre and D. Pauly, 2002. The FAOICLARM Stock Assessment Tools (FISAT-II) User's Guide. Computerized Information Series, FAO., Rome, Italy.

Gole-Bi, G.G., K.J.D. Koffi and S.G. Dadi, 2005. Contribution Socio-Economique de la Peche Artisanale en Cote D'Ivoire. FAO, DFID, PMEDP, United Kingdom, pp: 49.

Gourene, G., G.G. Teugels, B. Hugueny and D.F.E. Thys van den Audernaerde, 1999. Evaluation de la diversité ichtyologique d'un bassin ouest africain après la construction d'un barrage. Cybium, 23: $147-160$.

Grandcourt, E., T. Al-Abdessalaam, F. Francis and A. AlShamsi, 2007. Population biology and assessment of the white-spotted spinefoot, Siganus canaliculatus (Park, 1797), in the southern Arabian Gulf. J. Applied Ichthyol., 23: 53-59.

Gulland, J.A., 1971. The Fish Resources of the Ocean. 1st Edn., Fishing News Books, London, pp: 255.

Kantoussan, J., 2007. Impacts de la pression de pêche sur l'organisation des peuplements de poissons: Application aux retenues artificielles de Sélingué et de Manantali, Mali, Afrique de l'Ouest. Ph.D. Thesis. Ecole Nationale Supérieure Agronomie Rennes (ENSAR), France. pp: 195.

Kone, T. and G. Teugels, 1999. Données sur la reproduction d'un tilapia estuarien (Sarotherodon melanotheron) isolé dans un lac de barrage ouestafricain. Aquat. Living Resour., 12: 289-293.

Lae, R., J.M. Ecoutin and J. Kantoussan, 2004. The use of biological indicators for monitoring fisheries exploitation: Application to man-made reservoirs in Mali. Aquat. Living Resour., 17: 95-105.

Leveque, C., 1999. Les Poisons des Eaux Continentales Africaines: Diversite, Ecologie, Utilisation Par L'homme. IRD, Paris, pp: 521.

Leveque, C., D. Paugy and G.G. Teugels, 1992. Faune des poissons d'eaux douces et saumâtres de l'Afrique de l'Ouest, Tome 1 and 2 ORSTOM, Paris, France MRAC. Vol. 2 Tervuren Belgium pp :902.

Longhusit, A., 2002. Murphy law revisited: longevity as a factor in recruitment to fish populations. Fish. Res., 56: 125-131.

Moreau, J., J. Arrignon and R.A. Jubb, 1988. Les Introductions D'especes Etrangeres dans les Eaux Continentales Africaines: Interets et Limites. In: Biologie et Ecologie des Poissons d'eau Douce Africains, Leveque, C., M.N. Bruton, G.W. Ssentongo (Eds.). Orstom, Paris, pp: 395-425.
Moreau, J., U.S. Amarasinghe, B. Sricharoendham, R. Prabath, P.K. Jayasinghe, A. Kumara and M.C. Villanueva, 2008. Population Dynamics of Commercially Important Fish Species in four Asian Reservoirs. Backhuys Publishers, Leiden, The Netherlands.

Niyonkuru, C., P. Laleye, M.C. Villanueva and J. Moreau, 2003. Population parameters of main fish species of lake Nokoue in Benin. Proceedings of the 3rd International Conference of the Pan African Fisheries Society, Nov. 10-14, Cotonou, Benin, pp: 216-216.

Ouattara, M., G. Gourene and A.F. Vanga, 2006. Proposition de fermeture saisonniere de la peche en vue d'une exploitation durable du poisson au lac d'Ayame (Cote d'Ivoire). Tropicultura, 24: 7-13.

Ouattara, A., G. Gourene and N. Podoor, 2007. Activite photosynthetique du phytoplancton dans le barrage hydroelectrique d'Ayame I (Cote d'Tvoire). Agronomie Afr., 19: 63-70.

Patterson, K., 1992. Fisheries for small pelagic species: An empirical approach to management targets. Rev. Fish Biol. Fish., 2: 321-338.

Pauly, D., 1980. On the interrelationships between natural mortality, growth parameters and mean environmental temperature in 175 fish stocks. ICES J. Mar. Sci., 39: $175-192$.

Pauly, D., 1984. Length-converted catch curves: A powerful tool for fisheries research in the tropics (Part II). Fishbyte, 2: 17-19.

Penha, J.M.F. and L.A.F. Mateus, 2007. Sustainable harvest of two large predatory catfish in the cuiba river basin, Northern pantanal, Brazil. Braz. J. Biol., 67: 81-89.

Reizer, C., 1967. Amenagement Piscicole du lac Artificiel D'Ayame. Centre Technique Forestier Tropicale, Nogent-sur Marne, pp: 108.

Santos, M.M., C.C. Monteiro and K. Erzini, 1995. Aspects of the biology and gillnet selectivity of the axillary seabream (Pagellus-acarne, Risso) and common pandora (Pagellus-erythrinus, Linnaeus) from the Algarve (South Portugal). Fish. Res., 23: 223-236.

Tah, L., K.S. Da Costa, J.N. Kouassi and J. Moreau, 2009. Effort de peche et production piscicole au lac d'Ayame I (Bassin de la Bia; Cote d'Ivoire) apres le depart des pecheurs Bozos. Agronomie Africaine, 21: 103-115.

Villanueva, M.C., 2004. Biodiversite et relations trophiques dans quelques milieux estuariens et lagunaires de l'Afrique de l'ouest: Adaptations aux pressions environnementales. Ph.D. Thesis, Institut National Polytechnique de Toulouse (INPT), France, pp: 272 . 